\title{
XI. A sketch of the topography and geology of Lake Ontario
}

\section{J.J. Bigsby M.D. F.L. and G.S.}

To cite this article: J.J. Bigsby M.D. F.L. and G.S. (1829) XI. A sketch of the topography and geology of Lake Ontario, Philosophical Magazine Series 2, 5:26, 81-87, DOI: $10.1080 / 14786442908674925$

To link to this article: http://dx.doi.org/10.1080/14786442908674925

册 Published online: 10 Jul 2009.

Submit your article to this journal

Џ Article views: 3

Q View related articles $\asymp$ 
THE

PHILOSOPHICAL MAGAZINE

A N D

\title{
ANNALS OF PHILOSOPHY.
}

\author{
[NEW SERIES.]
}

\author{
$F E B R U A R Y 1829$.
}

XI. A Sketch of the Topography and Geology of Lake Ontario. By J. J. Bigsby, M.D. F.L. and G.S., For. Mem. Amer. Phil. Soc. \&c.

\author{
[With a Map.]
}

[Continued from p. 15.]

Topography of the Outlet of Lake Ontario, including the Lake of the Thousand Islands.

THE outlet of Lake Ontario, known as the River St. Lawrence, Iroquois or Cataraqui, is placed at the north-east end of the lake, and runs N.E. as far as Montreal (202 miles); with the exception of the small portion by the township of Cornwall, at the head of Lake St. Francis, and of the forty miles above Montreal; in both cases the change being to the E.N.E. At present we are only concerned with the gorge of the lake, the upper fifty-eight miles of the St. Lawrence, included between the towns of Kingston and Brockville, a space distinguished from that below by very marked features; as its breadth, the form of its shores, the number of its islands, and its being chiefly occupied by primitive rocks.

Of the country surrounding the outlet I am only personally acquninted with that on the Canadian shore. I am informed, and $\mathrm{I}$ partly know, that there is little difference on either side. The districts on the north are rendered rugged, unsightly, and comparatively unproductive by the great prevalence of naked or ill-clad ridges of rock; they are usually only from twenty to forty feet high, and very seldom rise into hills, unless it be in the interior; as about the Loughborough chain of lakes, and at the sources of the Gananoque river. These ridges vary from the state of complete ruin, in large angular blocks, to that of round-backed and glazed mounds;-in most cases elongated in a north-east direction. They are commonly placed near New Series. Vol. 5. No. 26. Feb. $1829 . \quad M \quad$ each 
each other; the narrow interspaces being covered with rich soil, and occasionally with pure red clay or siliceous sand, in very great quantity. But interspersed among these rough tracts, and more frequently towards the limits of the fifty-eight miles, there are plains of several square miles in extent." The largest I saw is twelve miles from Kingston;-based on limestone. Others are on the west of and near Brockville;-more uneven indeed, and based on sandstone.

The points of reference on the north main of the outlet are very few. It is thinly inhabited. Eighteen miles N.E. of Kingston is the village and river of Gananoque: the former consisting of five or six houses, and a good saw-mill on the west side of a fall near the mouth of the latter, which is a good harbour for vessels, and has a commodious natural quay. 'The river rises in a picturesque chain of lakes eighteen to twenty miles direct from the St. Lawrence, and in its route undergoes three descents. It is small in breadth, but discharges a good deal of water. Half-way between Kingston and Gananoque there is a tolerable inn on the land-route, and at the same distance between that village and Mallory's 'Town there is another. Mallory's Town consists of five or six tolerable houses on the road from Kingston to Montreal, in a large cleared plain two miles from the St. Lawrence, chiefly of clayey soil, and sprinkled with primitive mounds. Passing thence north-eastwards about one mile and a half, we find ourselves, for five or six miles, among an increased number of ridges with the usual imperfect and dreary clothing, when they again become less and less frequent; habitations become numerous, the ground merely undulates, and is often strewn with wide-spread but low heaps of ferruginous sand; and so it continues to Brockville, a very thriving town on the banks of the St. Lawrence, many of whose houses would be respectable in the first city in Europe. There are about 150 houses, in a principal street parallel to the St. Lawrence and some cross-streets. It is sheltered in the rear by woody heights with a winding creek interposed, which, after turning a saw-mill, falls into the River St. Lawrence, on the west side of the town.

The outlet itself flows over a surface the same as that which has just passed under review, but in a state of inundation. It may be said to commence $2 \frac{1}{2}$ miles S.W. of Gravelly Point* at the nameless angle of a considerable bend to the S.E. The distance from this angle to the opposite Canadian shore is nearly that between Cape Vincent and Kingston, which in a straight line carried over Grand Island is 9 miles 1490

\section{* Sometimes called Cape Vincent.}


yards. This breadth gradually diminishes, as is shown in the following admeasurements, taken (like the one just stated) from the maps of the Boundary Commission under the 6th and 7th articles of the Treaty. of Ghent. They are so taken as to exhibit the mean progressive contractions.

Miles.

At 6 miles direct below Kingston, at the upper end

At Gananoque to the S.W. angle of a great bay on the South Main................................... $\}^{6 \frac{9}{35}}$

At 3 miles direct below Gananoque, across the bottom of Grindstone Island........................ $\} 6 \frac{33}{100}$

$\left.\begin{array}{c}\text { At } 7 \frac{2}{3} \text { miles direct below ditto across the bottom of } \\ \text { the smaller division of Wells Island......... }\end{array}\right\} 4$

At across the head of Tar Island ................... $2 \frac{3}{4}$

At $5 \frac{1}{3}$ miles direct below last point, and across the bottom of Grenadier Island..................... $\} 3 \frac{8}{13}$

At $1 \frac{2}{3}$ mile direct below Block-house Island* to the bottom of Chippewa Bay....................... $\} 4_{1}^{1} \frac{1}{17}$

At Chippewa Point on the S. shore ................. $2 \frac{1}{7}$

From Chippewa Point a gradual but considerable contraction ensues for $3 \frac{2}{3}$ miles downward; with tolerably regular shores. About three miles, above Brockville, at a spot somewhat crowded with islands, the outlet is only 1500 yards broad, and opposite to that town it is exactly a geographical mile across.

It would be useless and tedious to describe in detail the very intricate district of waters now under consideration. Its shores are of mingled rock and marsh ; the former never rising higher than 150 feet, and seldom so much. The occasional patches of level and productive land are usually in the larger islands. The main and islands are broken into innumerable rushy coves and inlets; the larger receiving creeks which are bordered by morasses for some distance into the interior. These indents are sometimes large, particularly on the south main shore, as Candelles Bay $2 \frac{1}{4}$ miles broad, and 1535 yards deep; and twenty-one miles above Brockville; Goose Creek Bay thirteen miles above that town, and Chippewa Bay a little below the last named bay, and nearly two miles deep. These are all on the south shore.

The islands crowded into this space are upwards of seventeen hundred in number, as ascertained by the Boundary Commission. 'They are largest at the upper end, and most nu-

* Block-house Island is $7_{7^{3}}^{8}$ miles below the head of Tar Island, and 12. miles above Brockville. 
merous in the space of sixteen miles included between a point two miles and a half below Gananoque, and another, twentytwo miles above Brockville. The interval appropriately named " the Lake of the Thousand Islands," extends from Gananoque to within thirteen miles of Brockville. Its scenery has been depicted by Howison in his Sketches of Upper Canada a good deal too floridly, and in a way calculated to disappoint its visitors. It must, however, be admitted, that all that can be effected by ever changing combinations of isle and mainland moderately high, of rocks, woods and waters, unrelieved by hills in the distance, is done in a manner singularly beautiful.

The first fourteen miles from Kingston are almost wholly occupied by two very large islands, Long, Grand, or Wolfe, and Howe or Sir John Johnstone's Islands.

Grand Island, containing 31,283 acres*, is $17 \frac{3}{4}$ miles long in a north-east direction, and has its upper end (called Long

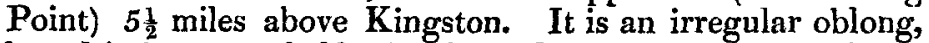
broad in its upper half ( $6 \frac{2}{3}$ miles wide at Kingston), and has a mean breadth of about a mile below Carleton Bay, a deep swampy indenture near the middle. Its point of nearest approach to the north main is 3 miles below Point Henry, and is a mile distant. That on the south main being $\frac{3}{4}$ of a mile, and situated a mile and two-thirds below Long Point above spoken of. The nearest part of the island is two miles distant from Kingston. It has been awarded to the British, to whom, in fact, it is indispensably necessary for the protection of their naval and military establishments on Lake Ontario. Its interior is nearly in a state of nature. It is fertile, level, low, and often swampy.

Howe Island, fertile and undulatory, is $8 \frac{2}{3}$ miles long, with an average width of $1 \frac{2}{3}$ mile. It is separnted from the north main by a channel of pretty uniform breadth, which sometimes is only $\frac{1}{4}$ of a mile. It is nearest Grand Island (with which it runs more or less parallel) at the upper end, and is there $\frac{2}{3}$ of a mile from it. The head of Howe Island is $5 \frac{1}{2}$ miles below Fort Henry.

These two islands have but few others around them. Of these the largest are Simcoe Island, at the head, and on the north of Grand Island, and Carleton Island on its south, opposite to the bay of that name. Simcoe Island is $3 \frac{2}{3}$ miles long and $a$ mile and a third in greatest breadth. Carleton Island is $2 \frac{1}{2}$ miles long, with a mean breadth of two-thirds of a mile.

Proceeding now below Grand Island, the next of great size, is the compact "Grindstone" Island, $5 \frac{2}{3}$ miles long by a mean

* According to Messrs. Thompson and Bird, astronomers. 
width of a mile and three quarters. It is $2 \frac{3}{4}$ miles from the north main, and 1 mile from the south, opposite Gananoque. It contains 5,316 acres (as stated by Messrs. T. and B.) and belongs to the United States.

"Wells" Island, consisting of 7950 acres, is $1 \frac{1}{7}$ mile below Grindstone Island, and is better described as two oblong and parallel islands joined near their top by an isthmus. The larger portion (running N. E.) is 8 miles long and 3 in greatest breadth; while the smaller is $4 \frac{1}{2}$ miles long and $\frac{2}{3} \mathrm{ds}$ of a mile in average breadth. The channel between this island and the south main is always very narrow, and in one place only two hundred yards across. It belongs to the United States, being always more than a mile from the north main.

Club Island (British) is $3 \frac{1}{3}$ miles long and one mile in greatest breadth, tapering at each end; in its upper third it lies close to the smaller division of Wells Island, the interval being often only thirty to forty yards, and containing also many islets. It is five hundred yards from the Canadian shore at its lower end.

Wells and Club Islands are in the heart of the Lake of the Thousand Isles, and are accordingly surrounded with multitudes of islands, large and small, very many being mere patches of rock. They universally run N.E. or nearly so, and are commonly narrow, with their sides steep or precipitous, and their extremities dipping gently into deep and clear waters. They are from twenty to a hundred feet high, and are for the most part well wooded with cedar, hemlock, pine, \&c., but frequently again are bare bleached rocks, smooth, glazed, or in large square fragments.

The next island of considerable size is some distance below "Wells." It is called "Tar Island," and is nearly two miles long by a mean breadth of $\frac{1}{4}$ of a mile. It is separated from the north main by a rushy shallow sixty yards broad. A few hundred yards S.E. of the head of 'Tar Island is Yeo's or Bald Rock Island, whereon is a great deposit of schorl.

Grenadier Island is $4 \frac{1}{2}$ miles long, its upper third ranging parallel to Tar Island, and in one place only four hundred yards distant. Opposite Smith's tavern on Tar Island it is $\frac{2}{3}$ of a mile from the north main, and is never less than a mile and a half from the south main. The breadth of Grenadier island is very irregular, but may be taken at six hundred yards as a mean. About two miles from its head it is nearly severed by two inlets from the opposite sides; the intervening isthmus being only eighty to a hundred yards broad. This island is elongated in a north-east direction, and contains 1070 acres; most of it under cultivation. It has been awarded to the British. 
Indian Hut Island, the only one remaining which requires distinct notice, guards the mouth of Groose Creek Bay. It is rocky, a mile and two thirds long, and from six hundred to seven hundred yards in average breadth. It is 360 yards from the eastern outer angle of the bay. It belongs to the United States.

\section{The Geology of Lake Ontario.}

The situations where the loose transported matters covering the fixed rocks of Lake Ontario particularly abound, have been noticed in the topographical part of this paper, and the inferences they lead to have been stated in the general view of the detritus of Canada, read before the Geological Society of London in the winter of 1826-7.

While the parallel ridge west and south of the lake is composed almost wholly of rock, the eminences bordering this body of water on the north-west are formed of these later deposits, which also overspread in great thickness the interval of thirty-seven miles between Lakes Ontario and Simcoe, and near the latter of which are penetrated for two hundred feet by the River Holland at Robinson's Mills. At that place, a hard well-cemented conglomerate of small primitive pebbles is now forming near the water level. It was altogether out of my power to make any very accurate observations on the nature and position of the component parts of the highlands of York and their vicinity alluded to above. I landed at the highest part of the cliffs six miles east of York, and found the castellated masses there to be of brown marl, effervescing smartly on exposure to acids, tolerably firm in its texture, and full of very small fragments of black limestone. But in the greater part of these heights, the lower half or thereabouts is occupied by a dark blue substance, either a clay or marl, and a yellow material which I take to be sand. This is particularly striking in the second bay from the east. In several places along-shore, about the middle of this line of precipices the beds of sand and clay seem to alternate. There is here so large an accumulation of diluvium, and it is so freely exposed by numerous and deep ravines, that it must be a very favourable spot for the discovery of animal remains: some of which indeed have been discovered in Lake Erie.

Boulders, numerous and of great size, abound everywhere. They are chiefly primitive, and can be referred to their parentrock in many cases, as in the instance of the milky quartz near Kingston, which extends in rolled fragments even to Lake Erie, having ascended the heights of Queenston. The remarkable augitic trap of Montreal is found in the Genesee 
Country; the primitive marble of Crow Lake and the Ottawa is plentiful on the north main of Ontario: the ophicalcic rocks, and tabular spar in large masses of Gananoque and the river just mentioned, are occasionally met with. Where the blocks of glassy tremolite occurring near Bellville come from, I know not. The tabular spar I found at this place, and a few miles east of Grimsby near the head of the lake. The ophicalcic boulder several tons in weight is on the beach in front of the town of York, a few yards from a minutely blended mass, weighing about two tons, of petalite, glassy actinolite, tremolite, quartz, calcspar, and a little copper-pyrites.

The first two of these substances only require remark. They have been described by Dr. Troost* in the following words: The petalite " occurs in crystalline masses of a grayish white colour, with a tinge of green. It has a confused lamellar texture: the laminæ offer in some directions a radiated texture, not unlike some varieties of tremolite, approaching even to fibrous, as cbserved in the asbestiform actinolite; the fibres are diverging; the laminæ are sometimes scaly and undulated. The cleavage approaches to a rhomboidal prism of $130^{\circ}$, which has again a diagonal cleavage. It breaks with difficulty, offering a rough lamellar and fibrous fracture; the fragments are angular with a glistening lustre, and in the direction of the laminæ somewhat pearly, more or less brilliant. It is strongly translucent on the edges, and strikes fire freely with steel; nearly of the same hardness with feldspar. Its specific gravity is 2.593. It melts with difficulty into an opaque white porous enamel; with borax, it gives a transparent glass. I fused a small quantity of the mineral with potash, dissolved the product in muriatic acid, and then evaporated it to dryness, and digested the mass in alcohol, by which it was partly dissolved and formed a solution which burned with a red flame, of a more dense colour than that of strontian. The quantity which I subjected to analysis was too small to enable me to ascertain the quantity of the lithia, and the proportion of the other ingredients. The actinolite which covers the petalite is very handsome: it seems to be a vein in which the crystals of actinolite of a fine green colour are cemented together by lamellar carbonate of lime. The crystals are nearly transparent, almost cylindrical, with the exception of a few which belong to the bis-unitaire, and the tri-unitaire of Haüy; the same form as those which are found at Franklin, New Jersey."

[To be continued.]

* Journal Acad. of Sciences, Philadelphia, vol. iii. p. 235.

XII. On 


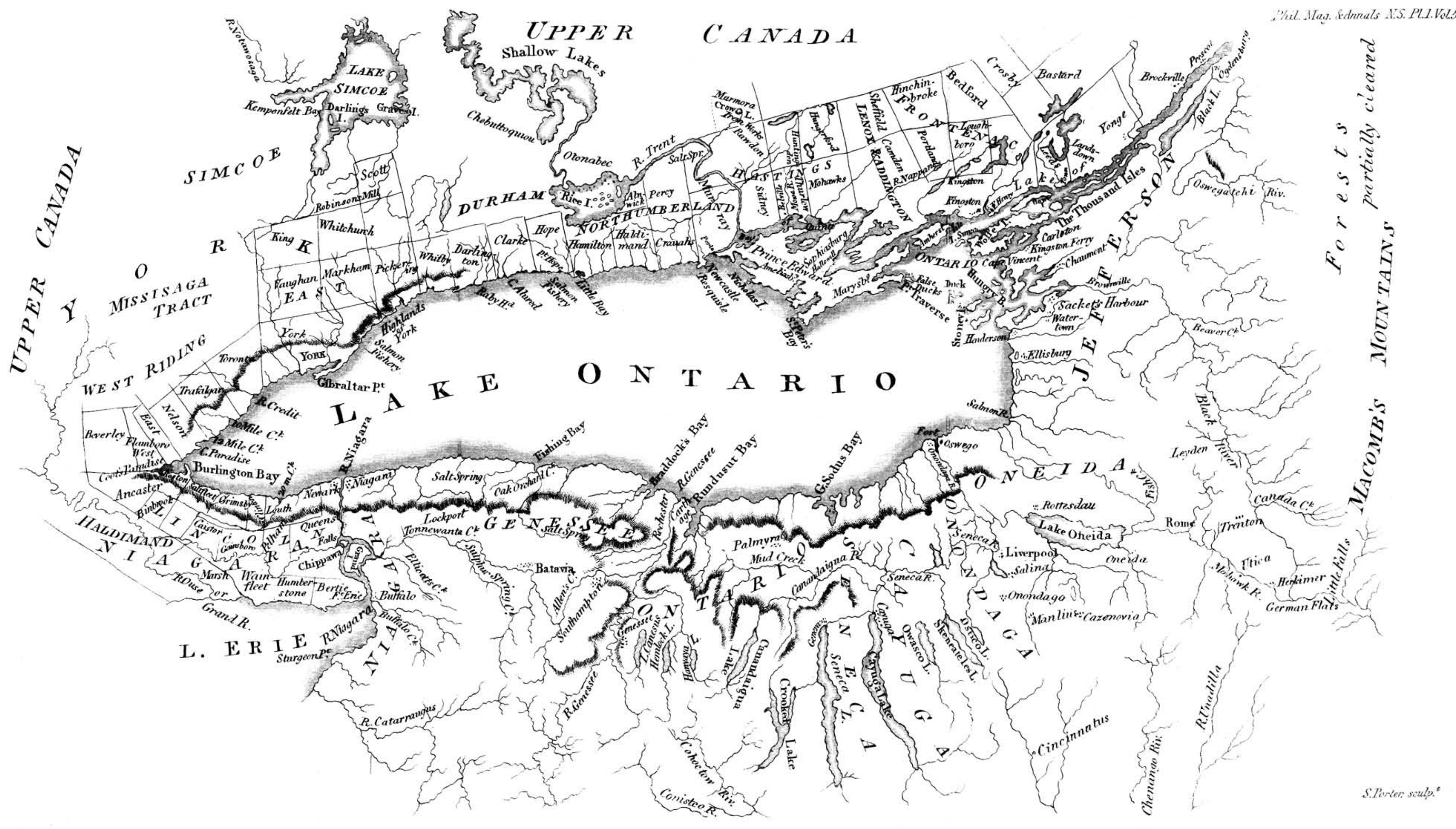

